\title{
Execution of Motor Vehicle Fiduciary Assurance by Debt Collector Azhar $^{*}$, Hirsanuddin $^{* *}$, Djumardin ${ }^{* *}$

\author{
*Postgraduate Student of Magister Law Study Program, Mataram University, Indonesia \\ ** Lecture of Law Faculty Mataram University, Indonesia \\ Jalan Pemudan No. 35. Mataram-83125, Tlp. (0370), Fax. 646919
}

Abstract: This study aims to find out and analyze the validity of the execution of Fiduciary Assurance by the Debt Collector in the form of objects of motor vehicle Fiduciary Assurance associated with the Fiduciary Guarantee Act and Financial Services Authority Regulations and legal protection against Debtors in the execution of the Fiduciary Guarantee by the Debt Collector.

The results showed that: The validity of the execution of the Fiduciary Guarantee by the Debt Collector on motor vehicle Fiduciary Assurance objects was associated with the Fiduciary Guarantee Act and Financial Services Authority Regulation, namely: Dept. Colecctor who did not fulfill formal juridical Article 50 Regulation of the Financial Services Authority Number 29/POJK.05/2014 concerning Business Management of Financing Companies is formal juridical disability, so that all actions taken by the Debt Collector in carrying out its duties as long as it is about the execution of fiduciary guarantees have an unauthorized or irrevocable effect. Whereas if the fiduciary guarantee is not registered then it is null and void because the fiduciary deed has a time limit for registration, null and void considered never existing. It is considered never existed because it involves object certainty, and legal protection against debtors in the execution of Fiduciary Guarantees by the Debt Collector, namely: in the form of preventive legal protection including the obligation of financial institutions to register fiduciary collateral objects and employ Debt Collectors who fulfill formal juridical requirements in accordance 50 Regulation of the Financial Services Authority Number 29/POJK.05/2014 concerning Business Operations of Financing Companies. Whereas Repressive legal protection can be in the form of errors committed by the Colector Dept. can be in the form of a matter, firstly, the business license of the Financing Company can be revoked, the second is civilly the Business Entity of the Financing Company can be compensated and the third is Criminal Debt Collector can be imposed Article 365 The Criminal Code as long as the criminal elements are fulfilled have the ability to be responsible.

Keywords: execution, fiduciary, debt collector

\section{Introduction}

Humans as creatures that always live in groups in a group called the community must need objects. There is no daily activity carried out by humans as members of the group without involving objects as supporters. Every member of the community, who pursues the pursuit of fulfilling their needs, is often hunting for objects to have so that their welfare will increase. ${ }^{1}$ The Indonesian government continues to improve in order to serve the demands of the needs of the people who are always developing according to the growth of the national economic climate, so that in the next step the Fiduciary Act was born following the issuance of the Mortgage Law. Some of the decades of this fiduciary guarantee institution have been developed by the world of jurisprudence, so that its existence has become so closely related to business people, especially in the effort of channelling loan funds to weak economic groups. ${ }^{2}$ Thus the people of the weak economic group can realize their desire to own an object even though the funds they have are insufficient to buy it in cash /

${ }^{1 .}$ H. Moch. Isnaeni, Pengantar Hukum Jaminan Kebendaan, Surabaya: PT. Revka Petra Media, 2016. p.1.

2. Ibid, p. 227-228. 
cash. The basic concept of a Fiduciary guarantee institution is the transfer of ownership rights to an object provided that the ownership rights are transferred it remains in the possession of the owner of the object. That is, the object that is the object of the agreement is only given the right of ownership, but in real terms the object is still in the debtor's control. - Law Number 42 of 1999 concerning Fiduciary Guarantees promulgated on 30 September 1999, hereinafter referred to as (UUJF).

Imposition of objects with Fiduciary collateral is made by Notary deed (Fiduciary Assurance deed), and must be registered with the registration of the fiduciary guarantee, the fiduciary registration office issues and submits fiduciary recipient of fiduciary guarantee certificate on the same date as the receipt of Article 14 paragraph (1) registration application UUJF.

Notary is one of the Officials involved in the registration of Fiduciary Guarantees, this is due to Notaries in Article 5 paragraph (1) jo. Particle 11 paragraph (1) of UUJF. Expressly states that the imposition of fiduciary collateral is made by Notary Deed in Indonesian Language and constitutes Fiduciary Guarantee Deed. Fiduciary Assurance is born on the same date as the date of Fiduciary Forgiveness in the Fiduciary List Book (article 14 paragraph (3) UUJF. In the Fiduciary Assurance deed the words' 'FOR JUSTICE BASED ON THE ALMIGHTY GOD' (Article 15 paragraph (1) UUJF The Fiduciary Guarantee Certificate has the same executive power as the court decision that has obtained permanent legal force, then the Fiduciary Execution is regulated in Article 29 paragraph (1) stating " if the debtor or Fiduciary is injured, execution of objects that are objects of fiduciary collateral can be done by:

a. Implementation of the executorial title as referred to in article 15 paragraph (2) by Fiduciary Recipients;

b. Sales of objects that are objects of Fiduciary Assurance for the power of the fiduciary recipient themselves through public tenders and take payment of their receivables from the proceeds of sale;

c. Underhand sales are carried out based on the agreement of the giver and recipient of Fiduciary if this can be obtained at the highest price that benefits the parties.

Further explanation in Article 34 paragraph (1) reads:

"In the event that the results of the execution exceed the guarantee value, the Fiduciary Recipient must return the excess to the Fiduciary Giver."

Based on the provisions of Article 21 to Article 23 and Article 50 of the Financial Services Authority Regulation Number 29/POJK.05/2014 concerning Business Operations of Financing Companies, provisions regarding the imposition of Fiduciary Guarantees by Financing Companies are as follows:

1) Article 21 paragraphs (1) reads: The Financing Company that carries out financing by imposing Fiduciary guarantees, is obliged to register the said Fiduciary at the Fiduciary registration office, in accordance with the Law governing fiduciary guarantees.

2) Article 22 reads: Financing companies must register fiduciary guarantees at the fiduciary registration office at the latest 1 (one) month from the date of the financing agreement.

3) Article 23 reads: Financing Companies are prohibited from executing collateral objects if the fiduciary registration office has not issued a fiduciary guarantee certificate and submitted it to the Financing Company.

4) Article 24 reads: Execution of fiduciary collateral by a Financing Company must fulfill the terms and conditions as stipulated in the law regarding fiduciary guarantees and agreed upon by the parties in the Financing Agreement.

5) Article 50 reads: Employees and / or Finance Officers who handle the collection sector are required to have a professional certificate in the collection field from the institution appointed by the association by submitting a notification to the OJK and accompanied by reasons for appointment.

Looking at and observing these provisions, of course the formal process with regard to the object and fiduciary agreement is stipulated in the Act Number. 42 of 1999 concerning Fiduciary and Regulation of the Financial Services Authority (POJK). To avoid the occurrence of a legal vacuum, the Regulation of the Chief of Police of the Republic of Indonesia was issued. 8 of 2011 which specifically regulates the security of the execution of fiduciary guarantees and the procedures for executing objects of fiduciary collateral can be carried out with the following requirements:

a) There is a request from the applicant;

b) Have Fiduciary Guarantee Deed;

c) Fiduciary guarantee is registered with the Fiduciary registration office; 
d) Fiduciary guarantees in the territory of Indonesia.

But in this case for the process of efficiency and effectiveness in securing fiduciary goods, often the creditor executes itself by using the services of a third party or outsourcing staff, the Debt Collector, even though this regulation has been in place since 2011, but in practice the field has not been fully implemented. In this case it will certainly lead to a situation that needs attention such as Intimidation, seizure, even acts of persecution if the debtor does not want to surrender the object of fiduciary collateral for various reasons, even though in the form of the fiduciary agreement there has been a default or failure to fulfill the fiduciary agreement.

Noting the conditions above, there is a gap between Das Sollen and Das Sein in terms of regulations and legislation and the application of friction in the execution of the Debt Collector to the Object of Fiduciary Assurance is not in accordance with Law No. 42 of 1999 and Authority Regulations Financial services are in effect, so that the execution process is often unwanted, such as:

1) The process of executing fiduciary collateral objects is not in accordance with the procedures stipulated in the financing agreement, including the stages of Fiduciary Guarantee Registration at the Fiduciary registration office as well as the stages of giving warning letters to the debtor / consumer;

2) The officer who executes a fiduciary object is an employee of a Financing Company or an Outsourcing Employee of a Financing Company who carries only an ID Card, an Assignment Letter and a Power of Attorney from a Financing Company or a outsourcing Company and does not have a Billing Professional Certificate issued by PT. Certification of Indonesian Financing Companies as institutions appointed by the Association of Indonesian Financing Companies as providers of certification;

3) Officers who carry out the execution of fiduciary collateral objects do not carry a fiduciary guarantee certificate, the fiduciary guarantee certificate has not been issued and submitted by the Fiduciary collateral registration office to the Financing Company;

4) The process of selling goods from the execution of fiduciary items is not carried out in accordance with the provisions of laws and regulations concerning fiduciary guarantees.

Based on the description contained in the background, the author proposes the following problems: 1). How is the validity of the execution of the Fiduciary Guarantee by the Debt Collector on the object of the motor vehicle Fiduciary Guarantee associated with the Fiduciary Guarantee Act and the Financial Services Authority Regulation? 2). What is the legal protection of the Debtor in the execution of the Fiduciary Guarantee by the Debt Collector?

\section{Research Method}

The type of research used by researchers is: the type of normative-empirical legal research, Sudikno Mertokusumo Mentioning "research carried out by reviewing the provisions of legislation (inabstracto) and seeing legal facts that occur in the field (inconcreto). In this case, it relates to the Execution of Motor Vehicle Fiduciary Assurance by the Debt Collector, using the statutory approach (Statue approach). This approach is carried out to examine all laws and regulations relating to legal issues being addressed. In addition, this study also uses a conceptual approach, which is done when researchers do not see the existing legal regulations. In using a conceptual approach, researchers need to demonstrate legal principles. As well as the sociological empirical approach, namely: an empirical approach that sees or pays attention to the applicability or application of legal rules, so that the differences between applicable laws and the implementation in the field are known.

This normative-empirical study uses the theory of authority, the theory of legal effectiveness and consumer protection theory as an analysis knife. The type of data used in this study, namely:

a. Primary data

Primary data in legal research is data obtained mainly from the results of empirical research, namely research conducted directly in society. ${ }^{3}$ Where in this study the data comes from field data obtained from respondents through interviews. Respondents in question are people or individuals who

\footnotetext{
3. Mukti Fajar dan Yulianto Ahmad, Dualisme Penelitian Hukum Normatif dan Hukum Empiris, First edition, Pustaka Pelajar, Yogyakarta 2010, p. 156.
} 
are directly related to the data needed. ${ }^{4}$ In this study the respondents are Debtors whose Objects are executed by the Debt Collector.

b. Secondary Data

Secondary data in legal research is data obtained from the results of a literature review or review of various literature or library materials related to problems or research material that are often referred to as legal material. ${ }^{5}$ Secondary data in this case contains legal material consisting of:

1. Material of Primary Law

Primary legal material, namely binding legal material consisting of laws and regulations. The rules used are the Criminal Law Book, Law Number 42 of 1999 concerning Fiduciary Guarantees, Law Number 8 of 1999 concerning Consumer Protection, Government Regulation Number 21 of 2015 concerning Procedures for Registration of Fiduciary Guarantees, Financial Services Authority Regulations Number 29/POJK.05/2014 Concerning the Business Implementation of Financing Companies, Financial Services Authority Regulation Number 30/POJK.5/2014 Concerning Good Corporate Governance for Financing Companies, Finance Minister Regulation Number 84/PMK.012/2006 concerning Financing Companies, Chief of Police Regulation Number 8 of 2011 concerning Safeguarding Execution of Fiduciary Guarantees.

2. Secondary Legal Materials

Secondary legal material, namely legal material that provides an explanation of primary legal material, as in this study which includes the draft law, the results of research or the opinions of legal experts.

3. Tertiary Legal Materials

Tertiary legal material is a legal material that provides guidance or explanation of primary legal materials and secondary legal materials, such as the Legal Dictionary, Indonesian Language Dictionary, and materials from the internet.

In conducting this research, the author wants to examine the Execution of Motor Vehicle Fiduciary Assurance by the Collector's Dept. and Legal Protection of Debtors. To examine this, the authors determined the study location in Bima District, Bolo District and Madapangga District. Consideration of the two Sub districts was chosen, because there was a lot of information that the authors heard that in the two sub parities often happened the Execution of Objects of Motorized Fiduciary Assurance by the Debt Collector.

In this study, the sampling technique used by the author is the Non-Probability or Non-Random technique. This method is the opposite of sampling probability, that is, each unit or human does not have the same

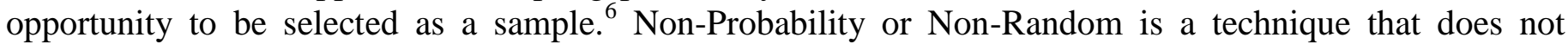
provide equal opportunities or opportunities for each element or member of the population to be selected as a sample.

Primary data collection techniques, namely by conducting interviews directly with respondents and informants. Respondents are people who are the subject of research and / or become the object of a particular problem/policy to subjectively perceive attitudes or perceptions, in this study, the Debtor who's Objects are executed by the Debt Collector. Informants are people who know practically and conceptually about certain things related to research because of their duties, positions and functions. The informant in this study is the Debt Collector. While secondary data, obtained by documentation study techniques, namely by reviewing and studying the literature materials relating to the problems to be studied such as books, scientific articles from research results and legislation relating to the object of research with qualitative descriptive analysis because examine the implementation of the law then after the data is collected, selected, compiled, explained, then analysed. The data analysis is carried out by the researcher carefully based on the type and purpose of the research conducted.

\section{Result and Discussion}

4. Ibid, p. 174

5. Ibid, p. 156

6. Amirudin dan Zainal Asikin, Pengantar Metode Penelitian Hukum, PT. Raja Grafindo Persada Jakarta, 2016, p.103. 


\subsection{The validity of the execution of the Fiduciary Guarantee by the Debt Collector on the object of a motor vehicle Fiduciary Guarantee is associated with the Fiduciary Guarantee Act and the Financial Services Authority Regulation}

\subsubsection{Conception about execution}

If we hear the words 'execution' then what will cross our mind is an implementation of Judge's Decision which is carried out forcibly by the Court. Indeed, such assumptions are not wrong, but in fact the scope of execution is far wider than just the implementation of a decision by the court, because execution does not always involve a Judge's Decision and certainly not only carried out by a court institution, for example execution by PUPN in the execution of State receivables or by a pawnshop institution on a Pawn object that has exceeded the redemption limit. All of the above are in line with what was presented by $\mathbf{M}$. Yahya Harahap that execution is nothing more than a continuous act of the entire legal procedure. ${ }^{7}$

In general, the execution of the field of civil law is indeed carried out by a court institution, either because of a Judicial Decision that has a permanent legal force, an arbitral award that has been exequatur by the District Court or other documents that have executive powers that can be executed through fiat Chair District Courts such as Mortgage Rights Certificate and Fiduciary Certificate, we say "in general" because the court is a symbol of the civil law enforcement process, although it is not always interpreted as such.

Because the court as an execution institution is generally based on civil procedural law in force in Indonesia, the court has the authority to execute both in real terms and in the form of paying a sum of money by conducting public auction. M. Yahya Harahap said that execution is a legal action carried out by the court to the party who loses in a case. ${ }^{8}$ Execution is only carried out on a condemnatory dictum or punishment dictum/command in a Judicial Decision, while a declalatoir and constitutive dictum does not contain an order to be carried out because it is only a statement.

It is often questioned about when actually the right to sell the collateral object for its own power arises, whether at the time the agreement regarding the guarantee for the financing provided is agreed or when the debtor begins to be declared in a default. It is true that the right of parate execution is always agreed at the beginning of the agreement, or even unnoticed by the parties that the right arises because in some cases the power clause to make sales on its own power has been stated in the guarantee deed form, however, if we review that when the principal agreement (Consumer Financing Agreement / Credit Agreement) runs smoothly and does not experience congestion, is it possible that the power to sell the collateral (parate execution) is already in the hands of the creditor? Maybe we can construct that right that has indeed been created or has existed since the agreement was agreed by the parties, but that right cannot be used if the principal agreement runs smoothly or at least is still blocked by certain conditions, because repayment of debt using collateral is an attempt to substitute if the debtor does not make his performance with payment normally.

From the logic above it means that the authority of the execution of parate which has been held by the creditor from the beginning can only be used since the debtor is in default, if until the end of the agreement period there is no default, then the authority of the execution parate cannot be used by the creditor and will itself since the debt guaranteed by the guarantee is paid in full, because as is the case for the accession of the guarantee agreement that always follows the principal agreement, then once the principal agreement is completed, the guarantee agreement will automatically be deleted.

If the parate execution can only be used when the last debtor is in default since when can the debtor in the financing agreement / credit agreement be defaulted? In an agreement that has determined the payment deadline, then the time when the default debtor will be regulated based on the agreement clause. In the credit agreement that determines the instalment obligations on a monthly basis, the default category will be determined based on the instalment payment period, for example in a bank loan agreement that the debtor is obliged to make instalments no later than the 10th of the month, if the debtor fails to perform as agreed upon, then since then the creditor has been able to exercise his right to parate the execution even though in the proper manner the bank will do the summons beforehand, perhaps the debtor has forgotten or is not in place so that he has no chance/unable to carry out his payment obligations even at generally the execution of

\footnotetext{
7. D.Y. Witanto, Hukum Jaminan Fidusia Dalam Perjanjian Pembiayaan Konsumen, Cetakan kesatu, Mandar Maju, Bandung, p. 223.

8. Ibid, p. 224.
} 
a new guarantee is carried out by the bank/creditor if the debtor has actually stopped paying up to several instalments.

According to M. Yahya Harahap said that basically there are two forms of execution in terms of the objectives to be achieved by the legal relations stated in the court ruling. Sometimes the target of legal relations to be fulfilled in accordance with the rules or dictum of a decision is to do something real action or real action so that this type of execution is called real execution. Sometimes the legal relationship that must be fulfilled by the decision is to pay a sum of money. Execution like this is always called execution of money payments. ${ }^{9}$

\subsubsection{Retrieving object collateral}

According to Zulhendra Diswar, Branch Manager of PT. FIFGROUP Bima Branch, needs to be straightened out first about the term 'execution' in the event of a credit congestion in installment payments by the recipient of the facility or the debtor in practice on the ground better known as "withdrawal". According to the Researcher's Results in the field in this case using the term "withdrawal" is not appropriate, because what was done by PT. FIFGROUP as a facility provider or creditor is to take back collateral items in accordance with the agreement clause that has been agreed before in accordance with Article 6 of the Financing Agreement on Injury Promises for Guaranteed Goods “ 10 , that is:

1. The debtor is declared to have committed a Promise Injury which, as time passes, is sufficiently proven and does not need to be proven again by a letter or anything but suffices with the occurrence of one or more of the following conditions:

a. The debtor is negligent and / or not and / or fails to fulfill one or more obligations as specified in this Financing Agreement.

b. Debtor is negligent and / or not and / or fails to make installment payments no later than when due.

c. Debtors are filed for bankruptcy, placed under custody, liquidation or file a postponement of debt repayments.

d. The debtor carries out an injury to the creditor based on the agreements and / or other agreements made and signed with the creditor.

2. In the event of an Appointment Injury, then:

a. The creditor has the right to demand repayment to the debtor, as the debtor agrees to make repayments of all debtor obligations, for immediate and at the same time paid off.

b. If the Debtor cannot pay the Debtor's Obligations to the Creditors, the Debtor agrees and binds himself to deliver the Goods and STNK to the Creditors as the Creditor has the right to take or receive the Goods and STNK to be sold in ways deemed good by the Creditor or through the authorized institution to sell goods for repayment of all / remaining Debtor Obligations after deducting costs incurred.

c. The debtor pays costs incurred as a result of the injury, including costs resulting from the delivery of goods to the creditor.

3. Submission and sale of Goods as referred to in paragraph 2 letter $b$ of this article does not mean that the Debtor has repaid Debtor Obligations that are still owed to the Creditors, if the proceeds of the Sale do not meet the Debtor's obligation to the Creditor, the Debtor is obliged to pay the Creditors all Paid creditors, and vice versa.

Execution according to Article 29 paragraph (1) of Law No. 42 of 1999 expressly states' If the debtor or Fiduciary is injured, the execution of the object that is the object of the Fiduciary Guarantee can be done by:

a. Implementation of the executorial title as referred to in article 15 paragraph (2) by Fiduciary Recipients;

b. Sales of objects that are objects of Fiduciary Assurance for the power of the fiduciary recipient themselves through public tenders and take payment of their receivables from the proceeds of sale;

c. Underhand sales are carried out based on the agreement of the giver and recipient of Fiduciary if this method can be obtained at the highest price that benefits the parties.

9. Ibid, p. 226-227.

10. Interview with the Branch Manager of PT. FIFGROUP, Tuesday 12 February 2019. 
Further explanation in Article 34 paragraph (1) states "In the event that the execution exceeds the guarantee value, the Fiduciary Recipient is obliged to return the excess to the Fiduciary." Execution is the execution of the executive title by Fiduciary Recipient, meaning direct execution can be carried out without going through justice and is final and binding on the parties to implement the decision. It is clear here that the execution of fiduciary guarantees based on the executorial title is that objects loaded with Fiduciary Assurance must be registered in accordance with Article 11 paragraph (1) of Law Number 42 of 1999 concerning Fiduciary Guarantees, the said imposition is regulated in Article 5 paragraph (1) " imposition with fiduciary is made by notary deed in Indonesian language and is a fiduciary deed further in Article 37 paragraph (3) If the period as referred to in paragraph (2) is not adjusted, then the Fiduciary Guarantee agreement is not a collateral right over the material referred to in Law Number 42 of 1999 concerning Fiduciary Guarantees and does not have an executive title based on the Fiduciary Guarantee Certificate as referred to in Article 15 paragraph (1) includes the words "For The Administration Based on the Almighty Gods."

To test the validity of the execution of the Fiduciary Guarantee by the Debt Collector on the object of a motor vehicle Fiduciary Assurance associated with the Fiduciary Guarantee Act and the Financial Services Authority Regulations, it must be measured in terms of the authority possessed by the Debt Collector who executes fiduciary guarantees. According to Philipus M. Hadjon in Buslianto, he gave the following views on authority:

a. Attribution is the authority to make decisions (besluit) which are directly sourced from the Law in the material sense.

b. Delegation is defined as the surrender of authority to make besluit, by Government officials (State Administration Officers) to the other party.

c. The mandate is defined as the delegation of authority to subordinates, the delegation of authority intends to authorize subordinates to make decisions a / $\mathrm{n}$ Administrative Officials of the State who give mandates. ${ }^{11}$

Taking into account the authority theory is faced with the position of the Debt Collector, the attribution of the authority of the Debt Collector in attribution has been regulated in Article 50 of the Financial Services Authority Regulation Number 29/POJK.05/2014 concerning the Business Management of the Financing Company, reads: The financing company outsourcing that handles the collection sector must have a professional certificate in the collection field from the institution appointed by the association by submitting a notification to the FSA and accompanied by the reason for the appointment.

However, the facts found in the field of Debt Collector who carry out the fiduciary guarantee execution process do not have a professional certificate in the collection field from an association-appointed institution. This means that in the legal subject to guarantee legal standing in the form of formal juridical certainty of legal subjects whose attribution is different from or not fulfilled the provisions of Article 50 of the Financial Services Authority Regulation Number 29/POJK.05/2014 concerning Business Management of Financing Companies, it can be said to contain formal juridical defects, so that all actions taken by the Debt Collector in carrying out their duties as long as the execution of fiduciary guarantees is invalid or can be canceled. Whereas if the fiduciary guarantee is not registered then it is null and void because the fiduciary deed has a time limit for registration, null and void considered never to exist. It is considered never because it involves the certainty of the object.

\subsection{Legal protection against Debtors in the execution of the Fiduciary Guarantee by the Debt Collector 3.2.1 Consumer finance}

Basically consumer financing is a type of consumer credit, which distinguishes only the credit provider where consumer financing is carried out by finance companies while consumer credit is provided by banks. Thus it can be said that the definition of actual consumption credit is substantively the same as consumer financing, namely:

"Credit given to consumers for the purchase of consumer goods and services as distinguished from loans used for productive or commercial purposes. Such credit can contain a greater risk than ordinary trade credit, so usually the credit is given at a higher interest rate. “12

11. Buslianto, Efektivitas Pembuatan Akta Peralihan Hak Milik Atas Tanah Melalui Jual Beli Oleh Camat Sebagai PPAT Sementara, Thesis for Postgraduate Notary at the University of Mataram, 2018, p. 14. 
Decree of the Minister of Finance of the Republic of Indonesia Number: 1251/KMK.013/1988 concerning Provisions and Procedures for Implementing Financing Institutions cq. Decree of the Minister of Finance of the Republic of Indonesia number: 448/KMK.017/2000 concerning Financing Companies confirms that the definition of Consumer Finance is financing activities for the procurement of goods based on consumer needs with installments or periodic payments by consumers. Besides that, this financing is closely related to the issue of collateral. Guarantee is a given to creditors to give rise to the belief that the debtor will fulfill obligations that can be assessed with money arising from an agreement. Guarantee Law is the whole of the legal rules governing the legal relationship between the giver and the recipient of the guarantee in relation to the imposition of collateral to obtain facilities/credit.

\subsubsection{Legal protection}

M. J. Leder stated that there was no such thing as creature as consumer law. Nevertheless, in general consumer law and consumer protection law are as stated by Lowe, namely: rules of law which recognize the bargaining weaknesses of individual consumers and which ensure that weakness is not unfairly explored. Because of the weak position of consumers, it must be protected by law. One of the characteristics, as well as the purpose of the law is to provide protection (protection) to the community. So, actually consumer law and consumer protection law are two legal fields that are difficult to separate and draw boundaries.

Az. Nasution states that the two terms are different, namely that the law of consumer protection is part of consumer law. Consumer law according to him is the overall principles and rules governing relations and problems between various parties with each other relating to goods and or consumer expectations, in the association of life. ${ }^{13}$

While the consumer protection law is defined as the overall principles and rules of law that regulate and protect consumers in relationships and problems with the providers of consumer goods and or services. ${ }^{14}$ More about that definition, Az. Nasution explained as follows: Consumer law basically plays a role in relations and consumer problems which are balanced in terms of socio-economic position, competitiveness, and education level. The ratio is that although it is not always right, each of them is better able to maintain and uphold their legitimate rights.

Consumer protection law is needed if the conditions of the parties holding legal or problematic relations in the community are not as balanced. Basically, both consumer law and consumer protection law discuss the same thing, namely the legal interests (rights) of consumers. How consumer rights are recognized and regulated in law and how to be enforced in the practice of living in a society that is the subject of discussion. Thus, the law of consumer protection or consumer law can be interpreted as a whole legal regulation that regulates the rights and obligations of consumers and producers that arise in their efforts to meet their needs. ${ }^{15}$

The whole word is intended to describe that in it includes all legal distinctions according to their type. This includes both the rules of civil, criminal, state administration, and international law. Its scope includes rights and obligations as well as ways of fulfilling it in its efforts to meet its needs, namely for consumers starting from businesses to obtain their needs from producers, including: information, choosing, prices up to the consequences arising from users' needs, for example to obtain compensation. Whereas for producers includes obligations relating to the production, storage, distribution and trading of products, as well as the consequences of using the product.

Article 1 number (1) Law No. 8 of 1999 provides an understanding of consumer protection as all efforts to ensure legal certainty to provide protection to consumers. Legal certainty to provide protection to consumers includes increasing the dignity of consumers and opening up access to information about goods and / or services for them, and developing the attitude of honest and responsible business actors (consideration of Law No. 8 of 1999).

\footnotetext{
12. Abdulkadir Muhammad, Rilda Murniati, Lembaga Keuangan dan Pembiayaan, PT. Citra Aditiya, Bandung, 2010, p.15.

13. Ibid, p. 19.

14. Ibid, p. 33 .

15. Dedi Harianto, Perlindungan Hukum Bagi Konsumen, Ghalia Indonesia, Jakarta, 2010, p. 12-14.
} 
Especially regarding consumer protection, according to Yusuf Shofie, consumer protection laws in Indonesia classify consumer protection norms into 2 (two) groups, namely: ${ }^{16}$

1. Actions that are prohibited for business actors;

2. Provisions regarding the inclusion of standard clauses.

The grouping is intended to provide protection to consumers from or due to actions taken by business actors. With regard to consumer protection can be specified the fields of consumer protection, namely as follows:

1. Physical safety;

2. Increasing and protecting the economic interests of consumers;

3. Standards for the safety and quality of goods and services;

4. Equal distribution of basic needs facilities;

5. Efforts to enable consumers to carry out compensation claims;

6. Educational programs and information dissemination;

7. Arranging special problems such as food, drinks, medicines and cosmetics.

The birth of the Law is expected to be a legal umbrella in the field of consumers by not closing the possibility of the formation of other legislation whose material provides protection for consumers. Definition of Consumer Protection According to Law Number 8 of 1999 concerning Consumer Protection, Article 1 paragraph (1), Consumer Protection are all efforts that guarantee legal certainty to provide protection to consumers.

In Article 4 of Chapter III of Act Number 8 of 1999 concerning Consumer Protection, specifically mentioning consumer rights, namely, among others:

1. The right to comfort, security and safety in consuming goods and/or services;

2. The right to choose goods and / or services and obtain said goods and/or services in accordance with the promised exchange rate and conditions and guarantees;

3. Right to information that is correct, clear and honest regarding the condition and guarantee of goods and/or services;

4. The right to be heard opinions and complaints about the goods and/or services used;

5. Right to get advocacy, protection, and efforts to properly resolve consumer protection disputes;

6. The right to get consumer guidance and education;

7. The right to be treated or served correctly and honestly and not discriminatory;

8. The right to obtain compensation, compensation and/or reimbursement, if the goods and/or services received are not in accordance with the agreement or not as appropriate;

9. Rights stipulated in the provisions of other laws and regulations.

The law for the protection of consumers provides more explanation to consumers regarding matters that must be considered by consumers in making legal relations with business actors. The legal relationship created between consumers and business actors is a legal relationship that provides benefits for both parties.

According to Philipus M. Hadjon distinguishes 2 (two) means of legal protection, namely:

1. Preventive legal protection aims to prevent the occurrence of disputes, which directs government actions to be careful in making decisions based on discretion.

2. Repressive protection aims to resolve disputes, including its handling in the judiciary. ${ }^{17}$

Taking into account the theory of legal protection from the Pilgrimage of M. Hadjon and obtained by the behavior of the Debt Collector in Kabupaten Bima who executes fiduciary guarantees, the debtor is constitutionally regulated and protected both in Law No. 42 of 1999 concerning Fiduciary Assurance, Law Law Number 8 Year 1999 concerningConsumer Protection, Regulation of the Financial Services Authority Number 29/POJK.05/2014 concerning Business Implementation of Financing Companies and the Criminal Code. Technically for legal protection Preventively for Debtors, it is stated that financial institutions are guided to register fiduciary collateral objects in accordance with Article 22 and 23 of the Financial Services Authority Regulation Number 29/POJK.05/2014 concerning Business Operations of Financing Companies.

16. Rita Herlina, Tanggung Jawab Negara Terhadap Perlindungan Konsumen Di Tinjau Dari Hukum Perdata, Perpustakaan Nasional, Jakarta, 2017, p. 24.

17. Phillipus M. Hadjon, Perlindungan Hukum Bagi Rakyat Indonesia, PT. Bina Ilmu, Surabaya, 1987, p. 29. 
Whereas for legal certainty in a formal juridical legal standing Debt Collector is regulated in Article 50 of the Financial Services Authority Regulation Number 29/POJK.05/2014 concerning Business Management of Financing Companies.

While Repressive legal protection is given constitutionally by the Constitution to the Debtor, if the Debt Collector does not fulfill formal juridical requirements regarding the legal standing in executing a fiduciary guarantee then administratively results in the permission of the company from the financing institution that employs the Debt Collector. administrative aspects, and do not rule out the possibility of being civilized, and for the Debt Collector will be subject to Article 365 of the Criminal Code because legally Criminal who does him who will be responsible as long as the criminal elements are fulfilled and the perpetrator (Debt Collector) has responsible abilities.

\section{Conclusion}

The validity of the execution of the Fiduciary Guarantee by the Debt Collector on the object of motor vehicle Fiduciary Assurance is associated with the Fiduciary Guarantee Act and the Financial Services Authority Regulations, namely: Debt Collector that does not fulfill formal jurisdiction Article 50 Regulation of the Financial Services Authority Number 29/POJK.05/2014 concerning the Business Operation of a Financing Company is a formal juridical defect, so that all actions taken by the Debt Collector in carrying out its duties throughout the execution of fiduciary guarantees result in invalid or can be canceled. Whereas if the fiduciary guarantee is not registered then it is null and void because the fiduciary deed has a time limit for registration, null and void considered never existing. It is considered never because it involves the certainty of the object.

Legal protection against Debtors in the execution of Fiduciary Guarantees by the Debt Collector, namely: in the form of preventive legal protection including the obligation of financial institutions to register fiduciary collateral objects and employ Debt Collectors who fulfill formal juridical requirements in accordance with Article 50 of Financial Services Authority Regulation Number 29 / POJK. 05/2014 concerning the Business Implementation of Financing Companies. Whereas Repressive legal protection can be in the form of errors committed by the Debt Collector can be in the form of a matter, firstly, the business license of the Financing Company can be revoked, the second is civilly the Business Entity of the Financing Company can be compensated and the third is Criminal Debt Collector can be imposed Article 365 The Criminal Code as long as the criminal elements are fulfilled have the ability to be responsible.

\section{References}

\section{Books}

[1] Abdulkadir Muhammad, \& Rilda Murniati. 2010. Lembaga Keuangan dan Pembiayaan. PT. Citra Aditiya, Bandung.

[2] Amirudin \& Zainal Asikin. 2016. Pengantar Metode Penelitian Hukum. PT. Raja Grafindo Persada Jakarta.

[3] AZ. Nasution,. 2011. Hukum Perlindungan Konsumen, Suatu Pengantar. Diadit Media, Jakarta.

[4] D.Y. Witanto. 2015. Hukum Jaminan Fidusia Dalam Perjanjian Pembiayaan Konsumen, Cetakan kesatu, Mandar Maju, Bandung.

[5] H. Moch. Isnaeni. 2016. Pengantar Hukum Jaminan Kebendaan. PT. Revka Petra Media, Surabaya.

[6] Mukti Fajar and Yulianto Ahmad. 2010. Dualisme Penelitian Hukum Normatif dan Hukum Empiris. First edition. Pustaka Pelajar, Yogyakarta

[7] Peter Mahmud Marzuki. 2005. Penelitian Hukum. Kencana, Jakarta.

[8] Philipus M. Hadjon. 1987. Perlindungan Hukum Bagi Rakyat Indonesia. Bina Ilmu, Surabaya.

[9] Rita Herlina. 2017. Tanggung Jawab Negara Terhadap Perlindungan Konsumen Di Tinjau Dari Hukum Perdata. Perpustakaan Nasional, Jakarta.

[10] Sudikno Mertokusumo. 2004. Penemuan Hukum. Liberty, Yogyakarta. 


\section{Regulations}

[1] The Criminal Code.

[2] Law Number 42 of 1999 concerning Fiduciary Guarantees.

[3] Law Number 8 of 1999 concerning Consumer Protection

[4] The Minister of Finance Regulation Number 84/PMK.012/2006 Concerning Financing Company, National Police Regulation Number 8 of 2011 concerning Safeguarding Execution of Fiduciary Guarantees.

[5] Financial Services Authority Regulation Number 29/POJK.05/2014 concerning Business Organizations of Financing Companies. 